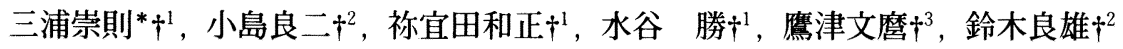 \\ 愛知県厚生連更生病院薬剤科 ${ }^{1}$ \\ 名城大学薬剂学部薬理学教室 $\dagger^{2}$ \\ 愛知県厚生連更生病院循環器内科 ${ }^{3}$
}

\title{
The Incidence of Adverse Reactions to Low Osmolar Iodine Contrast Media Caused by Coronary Angiography Examination and the Detection of its Risk Factors
}

\author{
TAKANORI MIURA ${ }^{*} \dagger^{1}$, RYOJI KOJIMA $\dagger^{2}$, KAZUMASA NEGITA $\dagger^{1}$, \\ MASARU MIZUTANI $\dagger^{1}$, FUMIMARO TAKATSU $\dagger^{3}$ and YOSHIO SUZUKI $\dagger^{2}$ \\ Department of Pharmacy Services, Kosei Hospital $\ddagger^{1}$ \\ Department of Pharmacology, Faculty of Pharmacy, Meijo University $\dagger^{2}$ \\ Division of Cardiology, Department of Internal Medicine, Kosei Hospital $\dagger^{3}$
}

$\left(\begin{array}{c}\text { Received Feberuary 5, } 1998 \\ \text { Accepted July } 16,1998\end{array}\right)$

The purpose of this study was to assess the incidence of the adverse reactions of low-osmolar non-ionic contrast media and its risk factors in patients receiving this contrast media for coronary angiography. We investigated all clinical data of 1386 patients who received non-ionic contrast media(Iopamidol, Iomeprol) from September 1995 to August 1996 for coronary angiography. The overall incidence of the adverse reactions of the drug was $31.5 \%$, but there were no severe or fatal adverse reactions. The predominant adverse reactions were nausea $(20.8 \%)$ and vomiting $(12.2 \%)$. The incidence of the adverse reactions in females $(51.9 \%)$ was definitely higher than that in males $(24.7 \%)$. In females in the menopause age period, the incidence of adverse reactions occurred at rate of $69.8 \%$, while in females in the non-menopause age, its incidence occurred at a rate of only $43.2 \%$. The incidence of the adverse reactions was much higher in the patients who had a history of allergy, renal impairment or previous adverse reactions to the contrast media. In addition, adverse reactions in the patients undergoing a coronary spasm test were also observed at a higher frequency. Furthermore, it was shown that the incidence of a delayedreactions to the drug was $8.7 \%$ ( 12 patients). These findings suggest that the monitoring of the adverse reactions after patients ingest a low-osmolar iodine contrast media is a necessary in order to acute adverse reactions as nausea and vomiting, as well as any delayed-reactions that may be induced by this contrast media. Furthermore, we propose that the menopause, which is peculiar to females may also be one of the risk factors for an increased occurrence of adverse reactions to this contrast media.

Key words - contrast media, coronary angiography, adverse reactions, delayed-reactions, risk factors 


\section{緒言}

近年, 画像診断法のめざましい発展とともに, 造影剤の使用頻度や使用量の増加が見られる. 冠 動脈疾患における緊急検査においても，造影剤を 用いた血管造影, 左室造影などの検査を必要とす る例が多くなってきている，造影剤による副作用 にはさまざまなものがあるが，大別すると，造影 片の物理的特性や化学毒性によるもので投与量依 存性の副作用と投与量に関係しない副作用の 2 つ に分けられる。最近開発された非イオン性低浸透 圧性造影剤は, 従来のイオン性造影郕より副作用 が少ないことから多用されるようになってきてい るが, 副作用の問題は完全に解决されたわけでは ない. また, 最近造影剤の副作用発現には，いく つかの危険因子の存在が大規模な疫学的調查 ${ }^{1)}$ により明らかにされてきている。したがって，患 者個々のもつ危険因子を造影㘊使用前に把握して おくことは，副作用予防の処置をしたり，リスク の高い患者をより注意深くモニターしていくこと で，重篤な副作用の予防と早期発見につながるの ではないかと考えられている。

当院では年間約 1600 症例の冠動脈造影 (coronary angiography, 以下, CAG と略す)検査が実施 されているが，造影剤使用に伴う副作用の発現率 の把握およびその危険因子に関して十分検討され てきていない，加えて，患者に対しても造影剤の 副作用（特に遅発性副作用）等の説明が十分され てきていなかった。そこで今回，『造影剤モ二 ター用紙』を作成し, 当院での造影剤の副作用の 発現率を調查した。さらに副作用発現の危険因子 について検討したので報告する。

\section{対象と方法}

対象は, 1995年 9 月 1 日から1996年 8 月31日の

$\dagger^{1,3}$ 愛知県安城市御幸本町12-38; 12-38, MiyukiHonmachi, Anjo, 446-8602 Japan

$\dagger^{2}$ 名古屋市天白区八事山 $150 ; 150$, Yajiyama, Tenpaku-ku, Nagoya, 468-8503 Japan
間に,当院循環器内科病棟に入院し, $\mathrm{CAG}$ ·経皮的 冠動脈形成術 (percutaneous transluminal coronary angioplasty，以下，PTCA と略す)等の検査または 治療を受けた患者1386例 [男性1039例(75.0\%)平 均年齢62.5歳，女性347例 $(25.0 \%)$ 平均年齢65.3 歳］全例である，検査治療法別症例の内訳は， CAG 検查 1072 例 $(77.3 \%)$, PTCA 治療 236例 (17.0\%) および PTCA+stent 治療78例 (5.6\%) で ある.

方法は，造影剤使用前日に Fig. 1 に示す『造 影剤モニター用紙』をもとに薬剤師がベッドサイ ドにおいて問診を実施した。すなわち，(1)患者 データ：性別，年齢，それまでの造影剤使用歴お よび副作用歴, アレルギー歴, 基礎疾患, (2)造影 検查, 治療および造影剤の種類：手技，用いる造 影剤と投与量, 前投薬の有無, (3)発生した副作 用: 発生, その症状, 重症度, 転帰等についてモ ニターを行った。さらに，造影郕使用直後から退 院時まで症状のモニターを続行するとともに，退 院時には遅発性副作用の説明を行った.

すべてのデータは，Fisher's exact testを用いて 統計学的検討を行った．危険率 $5 \%$ 以下を統計的 に有意とし，検定結果には次の略号を使用した.

$* * *: \mathrm{p}<0.001, * *: \mathrm{p}<0.01, *: \mathrm{p}<$ 0.05, N.S. : 有意な差なし

\section{結果}

\section{1. 造影剂使用後の副作用の総発現率}

Fig. 2 に造影剤使用後の副作用の発現率とその 内訳を示す，症状の総発現率は，31.5\%（436/ 1386例）と高頻度に認められた（各症例には重複 例がある). 特に嘔気・嘔吐といった消化器症状 は, $20.8 \%$ とその大部分を占め, そのうち激しい 嘔吐のために退院延期となった症例が $2.1 \%(29$ 例）認められた。一方, 血圧低下や心停止および 不整脈といった循環器症状は，11.1\%（154例） であることが明らかとなった。 また今回の調査で は，死亡例は認められなかった。 
造视乵モニター

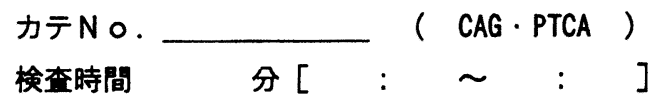

造影剂の種類と使用量

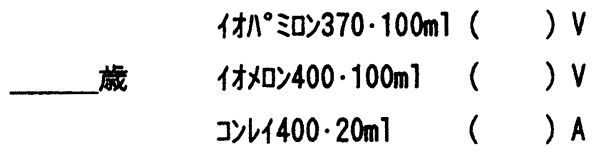

1) アレルギー体貿又は、アレルギー性の病気の有無

( 有·無)

1. 莱物アレルギー [

2. 食物アレルギー [

3. 喘息

4.アトビー性皮间炎

5.アレルギー性星炎

6. 花粉症

7. その他 (

2) 閉経

3）罱機能

検查前 $(）$

$$
\begin{aligned}
& B \cup N(\mathrm{mg} / \mathrm{dl}) \\
& \text { クレアニニン (mg/dl) }
\end{aligned}
$$

4 ) 甲状腺機能六進症（バセドー氏病）の既往歴の有無

$$
\begin{aligned}
& \text { （有－無） } \\
& \text { （有・無） }
\end{aligned}
$$

5 ）以前に造影検查を受けたことがあるか
1. 血管造影
2. その他 (

又、その際に何か症状はあったか

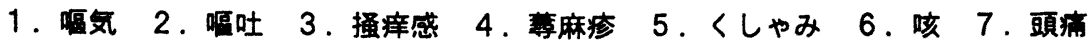
8. その他 (

6 ）今回、副作用予防のための前処置として薬绪を使用したか（使用 ·使用せず） 投与時間 [ : ] 菓剂名 [

7 ）スパスム誘発テストを試行したか （試行・試行せず）

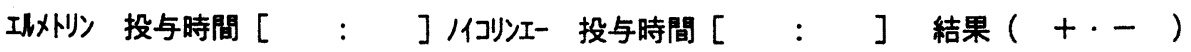

8 ）検查中又は、検查後に何か症状はあったか

(有・無)

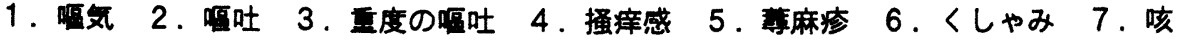
8. 頭痛 9. その他
時刻 [
処量
9 ）検查後に俭水できているか
10）検查後の排尿
（できた ・できず）
（有·無）

11）最終食毫摄取時問

検查前日 時 分

検查当日 時 分

絶食時間（）hr

Fig. 1. 造影剤モニター用紙 


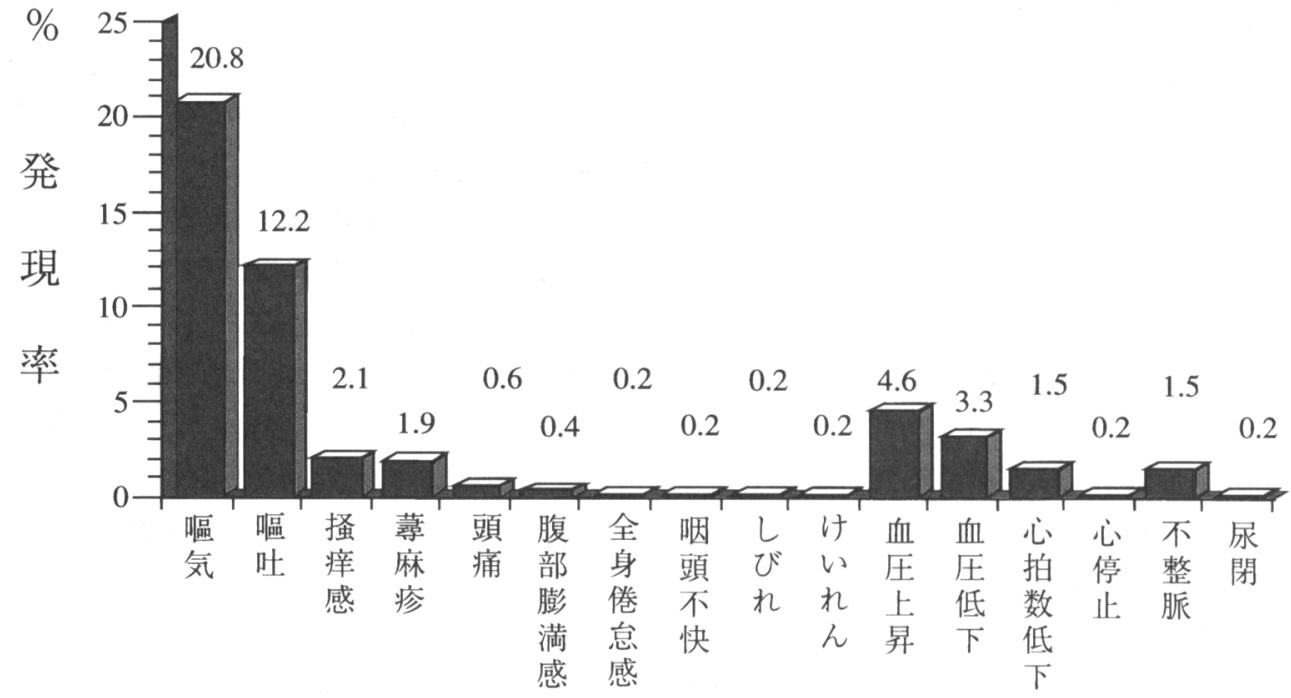

Fig. 2. 冠動脈造影検査後の症状とその発現率

\section{2. 各危険因子別の副作用の発現率}

各危険因子別の副作用の発現率の比較を Fig. 3 に示す. Fig. 3 A は性別による比較であ る。女性 $(51.9 \%)$ の方が男性 $(24.7 \%)$ に比 ベ，有意に高い副作用の発現率を示した。腎機能 低下の有無による比較では, 血清クレアチニン值 $1.5 \mathrm{mg} / \mathrm{ml}$ 末満の群（30.3\%）よりも血清クレア チニン值 $1.5 \mathrm{mg} / \mathrm{ml}$ 以上の群 $(53.6 \%)$ の方がよ り高い副作用の発現率を示した（Fig. 3 B)。アレ ルギー歴のある群 $(31.1 \%)$ では副作用の発現率 がアレルギー歴のない群 $(24.6 \%)$ に比しやや高 い傾向にあった(Fig. 3C)。さらに, Fig. 3 D は 造影剂副作用歷別の発現率示示。造影剤の副作 用歴のある群（50.8\%）での副作用の発現率は, 副作用の経験のない群 $(28.9 \%)$ と比較し, 有意 に高かった。

3. 検査や処置方法の相違による副作用の発現率

検査や処置法の違いによる副作用の発生頻度を Fig. 4 に示す．検査方法打よび治療方法の違いに よる副作用の発生頻度の違いでは, CAG 検査群 (28.7\%) に比較し，PTCA あるいは stent 治療群 (32.2\%) では, 副作用の発現率がやや高い傾向
にあることが示された（Fig. 4 A)．Fig. 4 B は冠 動脈スパスム誘発テストの試行・未試行の違いに よる副作用の発生頻度を示す。未試行の群 (27.3\%) に比し, 試行した群 $(38.0 \%)$ では, 副作用の発生頻度が有意に高いことが認められ た。さらに，冠動脈スパスム誘発テスト陽性例 (45.1\%) では，陰性例 $(35.8 \%)$ と比較して高 頻度に副作用が発生していた（Fig. 4 C).

\section{4. 副作用の発現率に及ぼす閉経の影響}

閉経前後に打ける副作用の発生頻度の違いを Fig. 5 に示す. Fig. 5 A は閉経前後による副作用 の発生頻度の比較である。閉経前 $(69.8 \%)$ の方 が閉経後 $(43.2 \%)$ に比し，有意に高い副作用の 発現率を示した。さらに, 閉経後 5 年以上の群 (31.5\%) に対し，閉経後 5 年未満の群(69.9\%) では, 副作用の発生頻度が有意に高いことが認め られた（Fig. 5 B).

\section{考察}

造影剂は，物理的作用（造影能）のみであれば 理想的であるが，実際はその化学的毒性により嘔 気・嘔吐，薵麻疹，血圧低下等の悪影響を及ぼす 


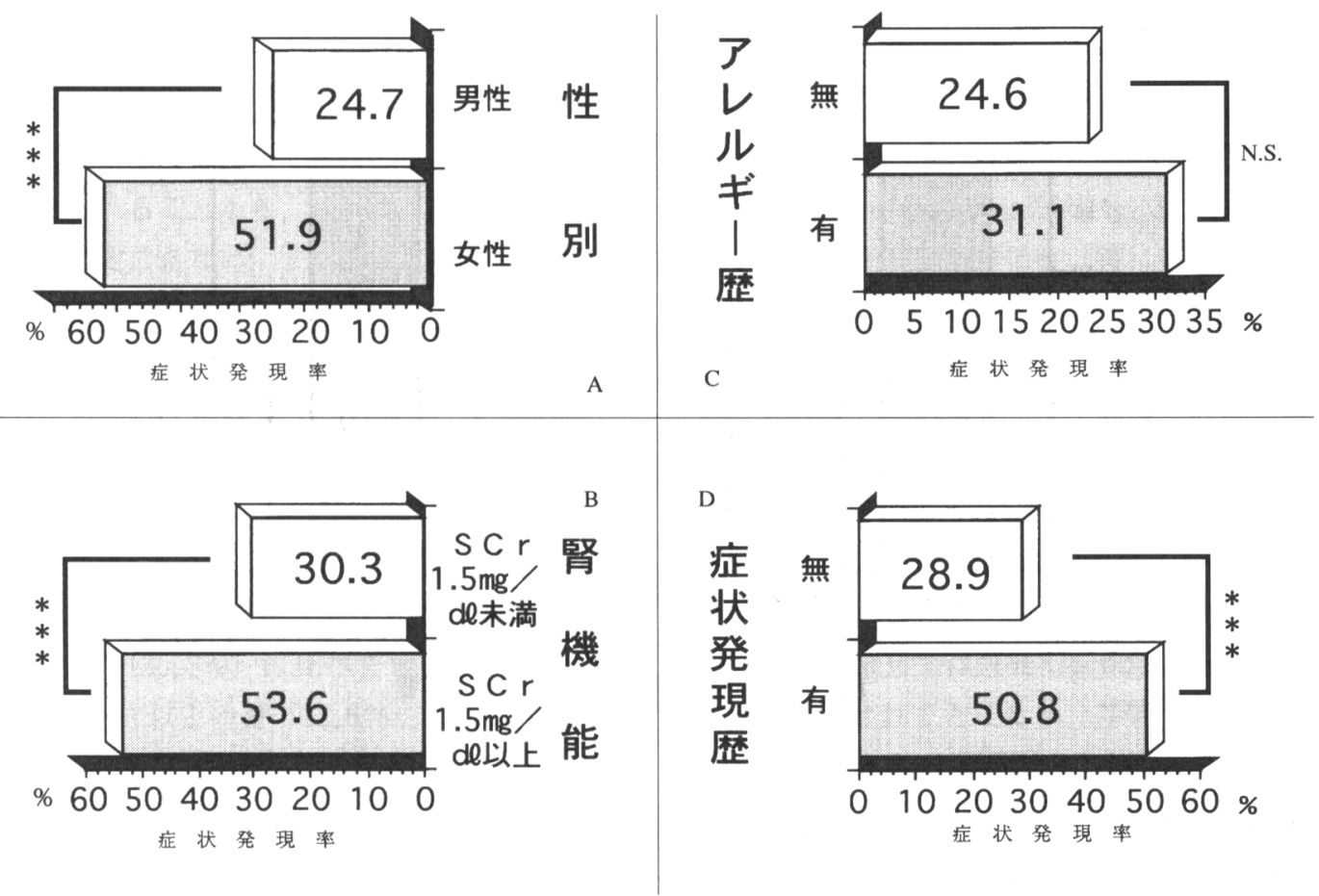

Fig. 3. 危険因子別の症状発現率の比較

検査・処置の相違

による症状発現率

の比較
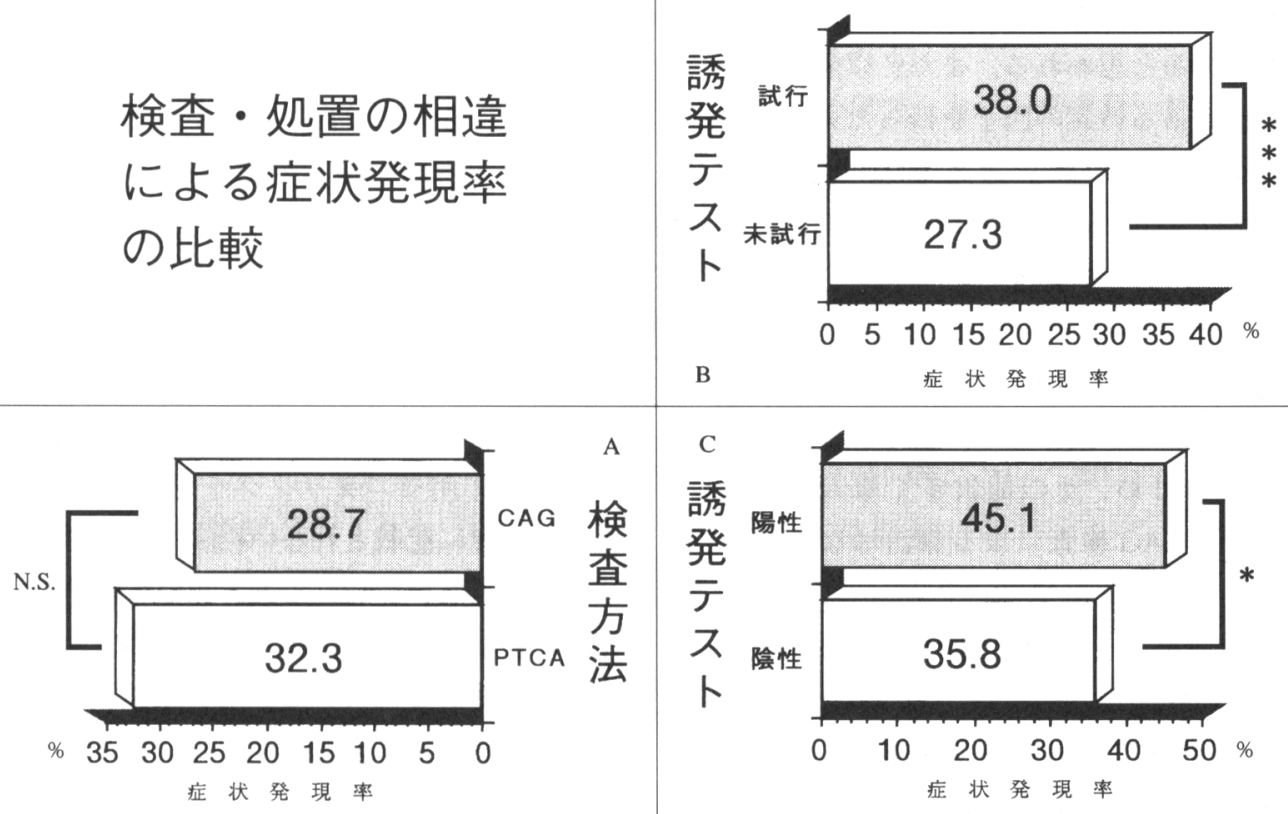

B 症状発現率

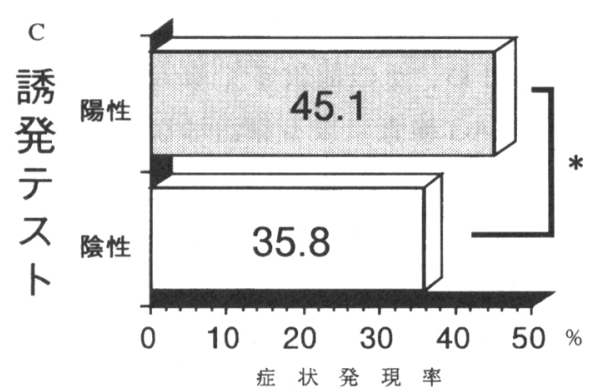


A

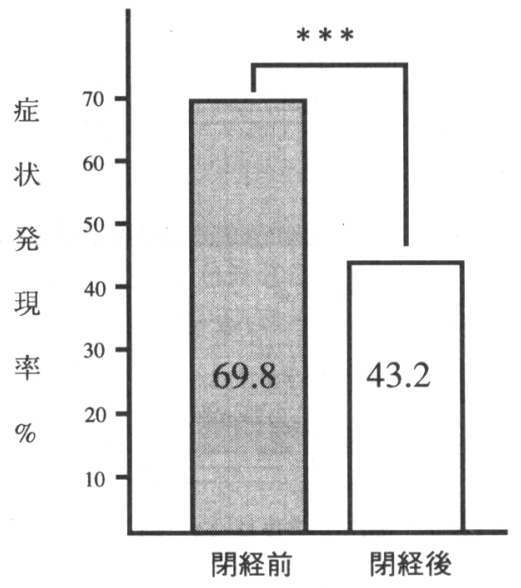

B

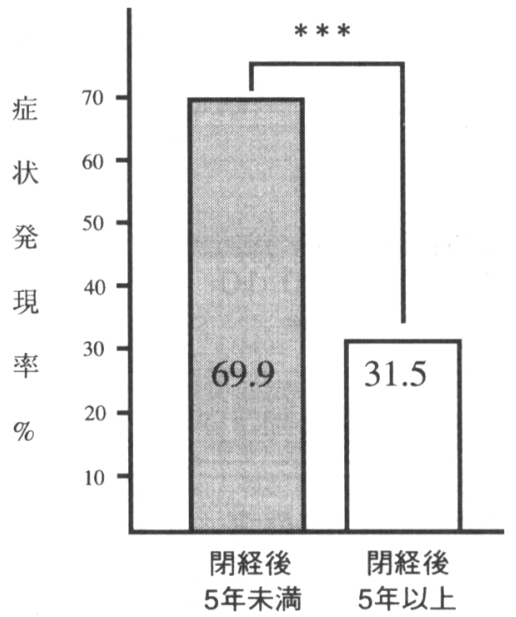

Fig.5. 症状発現率に及ぼす閉経の影響

ことがある。また，造影検査に伴って発生する嘔 気・嘔吐, 蕁麻疹, 血圧低下等の症状は必ずしも 造影剤の副作用によるものだけではなく, 検査手 抜や検查による精神的ストレスによっても引き起 こされると考えられている ${ }^{2)}$ ししたがって，これ らの症状を総括して造影検查に伴う症状として認 識する必要があると思われる。また，以前からこ れらの症状は，ある特定の因子を持った人に起こ りやすいのではないかと考えられてきてい る。1990年 Katayama ら ${ }^{1)}$ は, 造影剤副作用発現 の危険因子の大規模な調査を行った結果，造影剂 の副作用歴, アレルギー歴, 基礎疾患（心疾患） の因子を持つ患者で副作用が起こりやすいことを 報告している。また，副作用の発現率についても Katayama らをはじめ, その他数多く報告 ${ }^{36)}$ され てきているが，CAG 検査による報告はなされて きていない。

そこで今回我々は，CAG 検查による副作用の 発現率，さらに我々が予備検索により選択した因 子に関して，副作用との関連性を調査した。

今回の調査に打ける造影剤の副作用の発生頻度 は，1386例中436例で31.5\%であった（Fig. 2 ）。 使用した造影剤は全例非イオン性低浸透圧造影剤
である。非イオン性低浸透圧造影剤の副作用の発 生頻度については, Wolf らが0.69\%(50/7170 例) , Kuwatsuru $ら^{8)}$ が8.0\% (248/3085例) 並び に Katayama ら ${ }^{1)}$ が3.13\%(5276/168363例)と報告 している。これらの報告と比較して, 我々の今回 の副作用の発現率はやや高い值という結果となっ た。従来の大規模な報告のほとんどは, レトロス ペクティブな研究であり, カルテ上に記載された 副作用(出現した症状の対処療法を実施したも の）が論じられていると考える。我々も過去の データ（カルテ）在基に副作用の発現率を予備的 に調査したところ，その発現率は他の報告とほぼ 同程度であった。今回我々は, 冠動脈造影検査を 施行した全例に対してベッドサイドで，詳細に造 影剤の副作用モニタリングを実施したことによ り，カルテに記載されない軽度な副作用（対処療 法を実施しない症状）である嘔気・嘔吐をより高 頻度に検出でき，このことが従来の報告と差を生 じた原因であると考えている。事実，Wolf らは 副作用の種類についての詳しい分析は行っていな いが, Katayama $ら^{11}$ および Kuwatsuru $ら^{8)}$ の調査 では，嘔気・嘔吐の頻度はそれぞれ1.4\%および $1.6 \%$ あ゙あのに対し，今回の調査ではそれぞれ 
$20.8 \%$ よび12.2\%と高頻度に発生している (Fig. 2)。嘔気・嘔吐自体は軽度な副作用で, 今 回も血圧低下によるものは 4 例であった。さら に，その発生頻度に関して担当医による大きな違 いが認められることから, 造影剤以外の他の要因 の関与も否定できない．また，重篤な副作用との 関連も指摘されていないことから，他の副作用と は別に考えた方がよいと思われる。

他方, 危険因子の検索では「性別」「腎機能」 「造影剤の副作用歴」「冠動脈スパスム誘発テスト およびその結果」の 4 つの因子が副作用の発現と の間に因果関係を認めた。すなわち，腎機能と副 作用の発生頻度は, 血清クレアチニン值 $1.5 \mathrm{mg}$ / $\mathrm{ml}$ 末満の群 (30.3\%) に比べて血清クレアチニ ン值 $1.5 \mathrm{mg} / \mathrm{ml}$ 以上の群 $(53.6 \%)$ に高頻度に発 生しいていることが示された（Fig. 3 B). 非イオ ン性低浸透圧造影剤においても，腎臓に対する安 全性は, 従来のイオン性高浸透圧造影剤とほぼ同 等であるとの見解 ${ }^{-12)}$ もあり, 非イオン性低浸透 圧造影剤の時代を迎えても，腎障害に留意して適 切な処置を忘れてはならないことが再認識され た. 加えて, 脱水も腎障害の危険因子の 1 つであ り，一般にヨード造影剤使用時の前処置として禁 食にしていることが多く, この際に水分制限も同 時に行われてしまうことがあるので注意を要す る. 特に乳幼児や高龄者は脱水になりやすい傾向 があるので，造影剤の影響を受けないようにする ためには，十分な水分補給が必要となる。

造影剤副作用歴と副作用の発生頻度の関係にお いて，造影剤の副作用歴のある群 $(50.8 \%)$ で は, 副作用の経験のない群 $(28.9 \%)$ に比べ, よ り高い副作用発生頻度が示された（Fig. 3D). この傾向は従来の報告と一致する。また Witten $ら^{13)}$ は, 造影剤に対する副作用に関して, 莀麻疹 等のアレルギー反応の既往のある患者の方が, 嘔 気・嘔吐等の非アレルギー反応の既往のあるもの より, 造影剤再投与時により高い副作用の発生頻 度を示すと指摘している。

従来の報告では, アレルギー歴のある症例で
は, ない症例に比し, 副作用の発生頻度が高く, 約 2 倍から 7 倍という報告 ${ }^{13-16)}$ が見られる。しか しながら，今回の調査ではアレルギー歴のある症 例では若干副作用の発現率が高かったものの有意 な差は認められなかった（Fig. $3 \mathrm{C}$ )。このこと は，アレルギー歴の中でも，特に気管支喘息が比 較的副作用とよく相関するという報告 ${ }^{3)}$ があ り，我々の今回の調査においてもアレルギー歴の ほとんどが，食物・花粉症・鼻炎であり，気管支 喘息の患者はわずかに 7 例であったことに関係が あるかもしれない. 今後アレルギー歴に関して は，さらに詳細な検討を追加していく予定であ る.

加えて, 最近では遅発型副作用におけるショッ クが報告 ${ }^{17)}$ れてきており，遅発型副作用への対 応が問題視されてきている.今回のモニター開始 以前には，1件も報告されなかった当院での遅発 型副作用が12件 $(0.8 \%)$ 検出された。これらは いずれも軽症から中等症であったが, 当院では通 常 CAG 検査であれば検査当日，PTCA 治療であ れば治療翌日退院となっているため，特に今回の ような遅発型副作用に対する啓蒙活動は重要であ ると思われる。

今回の研究において興味深い知見は, 副作用の 発現率が男性より女性に高く認められた（Fig. 3 A）ことである。一般的に造影剤による副作用の 発現率には性差はないという報告1,3,5,14)が多い が，我々の研究において冠動脈造影検査における 造影剤による副作用の発生率は, 明らかに性差を 認めた。そこでさらにこの点について検討した結 果, 閉経後の群に比し, 閉経前の群では副作用の 発生率は有意に高いということが示された (Fig. $5 \mathrm{~A})$ ．さらに閉経後 5 年未満の群は, 閉経 後 5 年以上の群に対し, 著しく高い副作用の発現 率を示した (Fig. 5 B)。 また, 閉経後 5 年以上の 群における副作用の発現率は，男性のそれとほぼ 同程度であることが認められた(Fig. 5 B)，本研 究において対象となった女性は44歳以上で，その ほとんどが更年期に入っているものと考えられ 
る.この閉経を伴う更年期は，女性の一生の中で ライフステージに組み込まれた事象である．加齢 による卵巣重量の減少は40歳を境として生じると 言われ，これに伴って機能的にも卯巣性ステロイ ド，すなわちエストロゲンは急激に低下する。こ のエストロゲン欠乏状態の不安定な時期は，様々 な身体的変化をもたらすことが報告されてきてい る ${ }^{18-21)}$. 興味深いことに, 今回の研究において特 に女性に顕著に発生した副作用の各症状は，嘔気 ・嘔吐・頭痛・熱感・動悸・発汗立進・のぼせ等 であり，これらは更年期の症状とほぼ一致するも のであった，事実，冠動脈造影検查における年齢 分布において, 特に女性はその対象のほとんどが 閉経直前あるいは閉経後に集中している。したが うて，ホルモンバランスが不安定な状態にあると 考えられる閉経を含む更年期が，女性における造 影剤による副作用の発生頻度を高くする危険因子 であると推察される。この点に関しては，今後さ らに更年期の各種女性ホルモンの変化と副作用の 発現との関係についての詳細な検討が必要と考え る.

以上, 本臨床研究は, 当院における造影剤モ二 タリングが, 造影剤によって引き起こされるかも しれない副作用や遅発型副作用の発見に対して有 用であるということを示唆するものである. 加え て，腎機能低下，造影剤の副作用歴，冠動脈スパ スム誘発テストなどに加え，女性特有の更年期 が, 造影剤による副作用の発現率を増加させる危 険因子として考えられる。

\section{引用文献}

1) H. Katayama, et al., Radiology., 175, 621-628 (1990).

2) C. M. Arroyave, et al., J. Immun., 117, 18661869 (1976).

3) G. Ansell, Invest Radiol ., 5, 374-384 (1970).

4) G. Ansell, et al., Invest. Radiol., 15(Suppl), 32-39 (1980).

5) W. H. Shehadi and G. Toniolo, Radiology, 137, 299-302(1980).

6) F. G. Palmer, et al., Australas Radiol., 32, 426428 (1988).

7) G. L. Wolf, et al., A. J. R., 152, 939-944 (1989).

8) R. Kuwatsuru, et al., 順天堂医学, 39(1), 79-87 (1993).

9) F. Stacul, et al., A. J. R., 149, 1287-1289 (1987).

10) A. Nygren and H.R.Ulfendahl, Acta Radiol., 30, 383-389 (1989).

11) N. B. Aron, et al., A. J. of Kidney Disease, 3, 189-193 (1989).

12) G. Deray, et al., Am. J. Nephron, 11, 78-79 (1991).

13) D. M. Witten, et al., A. J. R., 119, 832-840 (1973).

14）東澄典, 片山通夫, 日本医放会誌, 50, 13591366 (1990).

15）木本龍也ほか，臨放， 25, 821-825 (1980).

16) H. Katayama, et al., 日本医放会誌, 48, 423432(1988).

17) P. N. Panto, et al., Brit. J. Radiol, 59, 41-44 (1986).

18) Aso T. and Aso K., Hormone Frontier in Gynecology, 2, 215-221(1995).

19) Yanihara T. and Akamatsu T, Clinical Endrocrinology, 46, 411-416 (1998).

20) Grady D. et al., Ann. Int. Med., 117, 10161037(1992).

21）赤松達也ほか，日本更年期医学会誌，2，106111 (1994). 